\title{
ATTENTION AS A FACTOR IN THE SCHOOL PERFORMANCE OF ADOLESCENTS
}

ABSTRACT. Attention represents a core of cognitive activity, it is an essential element of meaningful information processing and a key factor in self-regulation which is necessary for academic success. Despite this, there is only a small number of studies that examine the relationship between attention and school performance of adolescents. The aim of this research is an attempt to identify the components of attention which are relevant for academic achievement in adolescence. In addition, the aim of the research is also to determine potential differences with regard to the respondents' gender. The sample included 350 adolescents, aged between 14 and 16 years $(M=15.2)$, matched for their intelligence quotient, from different towns in Serbia. The following instruments were used - the Digit Span Test, Digit Symbol-Coding, the Trail Making Test, the Stroop Test, the Concentration Achievement Test (for measuring the components of attention), Raven's Progressive Matrices (as a measure of intelligence). The results indicate that academic achievement is highly significantly associated with a certain configuration of components of the function of attention (goal-oriented selectivity, resistance to distractions, attention maintenance and concentration), and that the performance of students with poor academic achievement differs significantly from the performance of students with better academic achievement $(p<0.01)$. The results imply that the academic achievement or failure of adolescents cannot be interpreted without taking into account the characteristics of their attention. In addition, the results also indicate the necessity to establish an educational program with an aim to encourage the development of the assessed components of attention, in

andjelao@beotel.net

This paper was submitted on August 20, 2017 and accepted for publication at the meeting of the Editorial Board held on September 19, 2017. 
order for adolescents to attain academic achievements adequate to their intellectual capabilities.

KEY WORDS: attentional control functions; goal-oriented behavior; self-regulation in learning; school performance of adolescents.

INTRODUCTION

School performance represents a manifestation of a level of realization of cognitive, functional, and educational teaching tasks, a reflection of the quantity and quality of acquired knowledge, breadth and level of the development of capabilities, breadth and level of adopted educational values. A successful student is a student who adequately mastered the knowledge, skills, attitudes, and forms of behaviour which are necessary for further learning (Nikolašević et al., 2014), or the one whose school performance is in sync with his/her capabilities, or the one who possesses a balance between what is planned and the resulting effect (Rayneri et al., 2006). In addition to all of the shortcomings of the current grading system in schools, school performance expressed in school grades still represents an important indicator of the achievements of students in the real world (Moss \& St Laurent, 2001), a basic indicator of educational achievements (Gadžić \& Milojević, 2009), as well as evidence formally identifying students as more or less successful persons (Havelka, 2000).

School failure, in turn, represents an ambiguous term which does not refer only to educational results, but also to the behaviour of students, their attitudes, beliefs, and formed system of values. For these reasons, school failure can have complex consequences when it comes to general development flows. The research of the causal relationships between behavioural problems and failure in school learning in childhood and adolescence (Hinshaw, 1992) state that the connection between school failure and adaptation difficulties has long been established. In terms of prevalence, personal and social suffering, and resistance to most intervention strategies, behavioural problems and school failure constitute the majority of problems in childhood and adolescence. Each domain predicts later maladjustment, which can lead to serious consequences in the form of various emotional disorders such as depression, anxiety or social phobia. Due to failure, the student loses both the confidence and 
motivation to continue the process of education (Madeeha \& Abdulbari, 2010).

The causes of school failure are many, and school performance of students is a result of the combined effects of numerous factors. Many classical and contemporary studies have determined a role of personal factors (general intellectual level, learning skills, personality traits, emotional status, motivation etc.) and social factors (family, school, peers, etc.) in school performance or failure. Although general intelligence explains $50-60 \%$ of the total variance of school performance, the remainder of the variance can be explained by other, non-cognitive factors, such as: personal activity, responsibility, motivation, effort, support of parents and the quality of teaching (Gottschling et al., 2012; Johnson, 2008; Spinath et al., 2006). Each of these factors is involved in the variance of performance with around $25 \%$, which means that a total of about $75 \%$ of the variance can be explained. The remaining, unexplained $25 \%$ can be attributed to a number of other factors, e.g. natural, organic, and socio-economic, etc. (Deary \& Johnson 2010).

Many studies also emphasize the self-regulatory capacity of students as an important factor of school performance (Mirkov, 2007), which represents the theoretical starting point of the research presented in this paper. By analysing some of the basic contemporary models of the self-regulation of learning in the process of education, Pintrich (Pintrich, 1999) emphasizes those theories that emphasize the volitional aspect of the self-regulatory processes necessary for achieving adequate school performance. So, in order for students to be able to learn, what is necessary is self-regulation, i.e. an active guidance and activation of cognitive, meta-cognitive, affective, and motivational resources in order to accomplish the necessary effects of learning (Boekaerts \& Corno, 2005). Self-regulation implies a process whereby students activate and maintain cognition, affects, and behaviour directed towards achieving goals (Zimmerman, 1990). The findings of neuropsychological studies of executive functions, the crown control mechanisms which underlie goal-oriented behaviour (Lezak, 2004; Guy et al. 2004), overlap to a large extent with the theory of self-regulatory processes.

Executive functions represent a set of cognitive processes including attentional control, inhibitory control, working memory and cognitive flexibility, as well as reasoning, problem solving, and planning - necessary for the cognitive control of behaviour: the 
selection and successful monitoring of behaviours that facilitate the attainment of chosen goals (Diamond, 2013; Chan et al., 2008). The very decision to carry out a certain activity, for example to learn, at its outset implies actively giving up on other opportunities and other events in the immediate environment, in the given existential situation, and focusing on the selected activity. This requires the ability to inhibit all irrelevant stimuli, and then it is possible to speak of focusing (Knudsen, 2007).

In this exceptional ability to direct and focus mental activity on a particular object, lies the essence and nucleus of the human ability to carry out goal-oriented activities which are primarily dependent on attention (Luria, 1973). It is due to the ability to direct and focus attention that a choice of a certain activity is made and that mental energy is directed towards it, and due to focusing, which we call enthrallment or concentration in every day speech, that the irrelevant stimuli or distractors are dismissed (Washburn, 2016). The direction and focusing of mental activity on a consciously set goal represents volitional, intentional or active attention. It is at the same time a precondition and result of human activity. It resulted from the involvement of mental activity in the process of work, and it enables man to ignore irrelevant stimuli for as long as it takes in order to finish the initiated goal-oriented activity. The intentional, active attention is one of the manifestations of will in man (Vygotsky, 1996; Malenka et al., 2009).

The tasks placed before the student by school learning, require an individual in this process (of active listening in class, participation in class activities, individually processing a text, remembering information, solving problems, solving tests, etc.) to direct attention away from all that is irrelevant in relation to the object of learning itself, as well as to maintain it for as long as it is necessary in order to carry out the goal activity (Latzman, 2010). School learning is directed towards the realization of future plans and is an instrument of the attainment of general life goals. Given this fact, school learning represents a typical form of volitional activity and it relies on deliberate, volitional attention. Verbal learning and verbal memory, which usually represent the basis of school success, are very complex psychological processes that start by an initial short-term memory record of information, via sensory memory in its visual or auditory modality (Awh etal., 2006). In order to transfer information into long-term memory, which is the ultimate goal of school learning, it is necessary to produce a 
conscious effort to maintain attention and repeat the teaching material, which allows for its encoding and consolidation. The learning of school material relies on declarative memory and the acquisition of cognitive routines, such as "learning how to learn or how to solve mathematical tasks" relies on implicit, non-declarative memory (Baddeley, 2003). The process of decoding a complex verbal message, received in a visual or auditory manner, implies an understanding of the exact meaning of the lexical elements, an understanding of syntactic relations and an understanding of the general meaning of the verbal material. Verbal learning is only possible with the participation of intact attention processes, since attention, as a complex functional system, allows for the selection, focusing, and maintenance of mental activity on significant external or mental contents (Maunsell 2002; Montalvo et al., 2004).

A lack of attentional control or an insufficient stability of even one of its components, reduces the efficiency of learning or renders it completely impossible. Poor attentional control, characterized by pronounced distractibility and weak concentration, is not suitable for the demands that need to be fulfilled by an adolescent aspiring to an excellent school performance. As a reminder, attentional control is defined as an ability to inhibit the first, dominant response, an ability to organize incoming stimuli, to maintain a calm state of mind, postpone pleasure, tolerate discomfort, and organize a cognitive and behavioural response to a selected, goal-oriented stimulus (Miller \& Esposito, 2005). Attentional control involves the focus of attention on a task, over a longer period of time, which implies a resistance to distractions by irrelevant stimuli in the surroundings. The problems of attentional control are associated with many forms of maladaptive behaviour or even with psychopathological symptoms in adolescence (Rueda et al., 2005).

Attentional control plays a key role in self-regulation, which is essential for school learning (Eisenberg et al., 2004). School performance requires that the adolescent maintain his/her attention on the task and continue the activity even when more attractive stimuli are imposed on him/her. In psychological terms, at the level of subjective experience, controlling attention from shifting to a more attractive goal or a distractor is associated with a feeling of effort. The orientation of attention towards stimuli that are appealing is performed effortlessly. If the attractive goal is irrelevant from the position of the task at hand or the realization of the goal, 
a great effort of will is needed in order to inhibit the response to irrelevant stimuli (Banich, 2009). Only a developed and stable volitional attention makes it possible to endure the necessary effort in order to keep all irrelevant stimuli under control. The improved ability of older children to increase mental effort is directly related to the development of volitional attention over the years. The process of learning and socialization implies a period of a transformation of non-volitional into volitional attention. The development of mature and autochthonous human activity implies the development and formation of a fully established volitional attention which, at first, requires a great deal of effort and energy expenditure but, in its ultimate stage, represents a shift from volitional to non-volitional attention, in which the expenditure of effort and energy is decreased again (Vygotsky, 1934; Astle et al., 2009).

In the process of developing volitional attention, school learning has an exceptional role. By focusing on school contents, children and adolescents master the ability to control the distractors, they dismiss excess information and move towards an independent and autonomous volitional attention. Not everybody progresses at the same pace on this road and individual differences are expected. It is expected that those adolescents who have reached a higher degree of volitional attention will have higher school performance.

Studies of attention and its components (goal-oriented selectivity, resistance to distractions, maintenance, and concentration) are most commonly organized in relation to the learning problems of younger school aged children or in connection with the problems of children and adolescents diagnosed with developmental hyperkinetic syndrome. The review of literature indicates an almost complete absence of studies dealing with the problem of attention in the context of school performance of adolescents from the general population. This may be one of the reasons that the inadequate school performance of unquestionably intelligent adolescents is, in school practice, usually explained by emotional factors, despite the fact that adolescents with inadequate school performance themselves often emphasize "poor concentration" when describing their learning difficulties, while their teachers describe them as "careless". Given the importance of school performance for general developmental flows, the significance of attention in the context of school learning and the lack of research of the connection of attention and the school performance of 
adolescents, the aim of this research is an attempt to identify the components of attention that are relevant for school learning in a younger adolescent age. In addition, the aim of this research is also to determine potential differences in terms of the students' gender.

\section{METHOD}

RESPONDENTS The total sample consisted of 350 students (5 groups of first grade secondary school students with different performance levels / 70 students in each category of school performance: insufficient, sufficient, good, very good, and excellent), from different towns in Serbia, aged between 14 and 16 years $(M=15.2 ; \mathrm{SD}=0.319)$, matched for their intelligence quotient ( $M=105$; min. 104, max. 107). The sample consisted of 175 students of both genders.

\section{INSTRUMENTS AND VARIABLES}

DIGIT SPAN

DIGIT SYM-

This digit-symbol substitution test also represents an integral part BOL-CODING (NUMBER SYMBOLS)

The Digit Span Test is an integral part of Wechsler's intelligence scale. Given that most authors agree that the subtest Digits Forward is a more reliable measure of attention, this research used only the Digits Forward results. The test consists of seven pairs of randomly selected number sequences, read out loud by the examiner, with the frequency of one number per second. The respondent's task is to repeat each sequence of numbers as presented by the examiner. When the respondent has repeated the sequence correctly, the examiner reads the next sequence with an addition of one more number, continuing until the respondent makes an error on both sequences in a pair. In the terms and procedures of statistical analysis, the achievement on this test was treated as an independent variable, as follows:

- DS (Digit Span) - the highest total number of repeated digits, as a measure of the capacity of attention. of Wechsler's intelligence scale. As is the case with all tests of this kind, it requires visual attention and concentration. It is considered a reliable test of attention, among other reasons, due to the fact that it is largely independent from intelligence. It consists of 100 small empty squares paired with squares containing randomly 
assigned numbers from 1 to 9 . Above these squares there is a printed instruction with different symbols corresponding to individual numbers (e.g. $1-, 5 \mathrm{U}, 9=, 60$ etc.). After a short practice, the task consists of the respondent filling in the empty squares with corresponding symbols (the duration of the task is 90 seconds). In the terms and procedures of statistical analysis, the achievement on this test was treated as an independent variable, as follows:

- NS (Number Symbols) - a number of successfully filled in symbols, as a measure of attention flexibility and vigilance.

TRAIL MAKING TEST (TMT)
THE STROOP TEST
This test consists of two parts, A and B. Part A consists of small circles spread out in a random order, with numbers from 1 to 25 written inside. The respondent is asked to connect all of the circles, from 1 to 25, without raising the pencil off the paper. Part B contains small circles with numbers and letters written inside. The respondent is asked to connect the circles respectively alternating between the numbers and letters following a sequence (e.g. 1-A, A-2, 2-B, etc.), as fast as possible, because the score represents the time needed for finishing this task. The results reflect the ability to concentrate, the flexibility, and distractibility of attention. This task is preceded by a short practice. In the terms and procedures of statistical analysis, the achievement on this test was treated as an independent variable, as follows:

- TMTtm1 - total time needed to connect the numbers, expressed in seconds, as a measure of visuospatial monitoring and concentration.

- TMTtm2 - total time needed to connect the letters and numbers, expressed in seconds, as a measure of flexibility and concentration.

Stroop tests are probably the best known and most frequently used tests for assessing the selectivity of attention. In this research, Dodrill's form of the test was used, consisting of a single paper containing 176 (11 horizontal and 16 vertical lines) names of colours (red, orange, green, blue), randomly printed in these colours. In part 1 of this test, the respondent reads the printed word. Part 2 requires that the respondent reads the name of the colour in which the word is printed. Time is carefully measured and recorded. Performance is evaluated according to the instructions, based on time 1 and time 2 . In the terms and procedures of statisti- 
cal analysis, the achievement on this test was treated as an independent variable, as follows:

- Strooptm 1 (reading words with an interference of colour) - total time, expressed in seconds, as a measure of attentional selectivity.

- Strooptm 2 - (naming of colours with an interference of conflicting words) - total time, expressed in seconds, as a measure of resistance to distractions.

THE CONCENTRATION

ACHIEVEMENT TEST
RAVEN'S

PROGRESSIVE

MATRICES

(RPM)
The test was conceived on the basis of the research conducted by Düker and associates, and it proved to be an excellent indicator of goal-oriented selectivity, maintenance of mental effort, and concentration. The most important task of the test consists of recording individual abilities of concentration, as a relatively independent personality trait. Its value is derived from the relative independence of its results from intelligence. It consists of 250 computation tasks (simple tasks of addition and subtraction), equal in their degree of difficulty. The expression of the ability of the respondent to concentrate is represented by the number of solved tasks as well as the number of errors made in 30 minutes, which is the duration of the test. In the terms and procedures of statistical analysis, the achievement on this test was treated as an independent variable, as follows:

- CATT - total number of tasks solved in 30 minutes, as a measure of attention maintenance, concentration and vigilance.

- CATC - number of correctly solved tasks, as a measure of the maintenance of the mental set and attention tenacity.

Raven's Progressive Matrices is a test designed to measure the general intellectual ability without the influence of cultural factors. Spearman's theory of the G-factor, according to which "general intelligence" is all the more convincing as the test is more homogenous, was used as a basis of this test. The first tests, based on the same idea, were constructed by I. C. Raven as early as in 1938 , but it still represents one of the best tests for assessing general intelligence today. From the original instructions for its use, it can be seen that the RPM is a non-verbal series for assessing general intelligence. The test requires the operations of analysis and comparison. Numerous factor analyses have shown that the test almost exclusively measures the $G$ factor. The result of the test is 
the sum of correctly solved tasks. The achieved results are interpreted according to the norms for the age group to which the respondent belongs. This test was chosen for reasons of practical nature, since it is the only test that could be used to test respondents of different ages. Given that intelligence was, in this study, just a control variable, it was possible to ignore, without consequences, the fact that this test is easy for highly intelligent respondents older than 14, and therefore not sufficiently discriminatory for those ages. In the terms and procedures of statistical analysis, the achievement on this test was treated as a control variable.

THE RESEARCH PROCEDURE
The respondents were tested on three occasions after the research goal was explained to them and their consent was obtained. The first stage included the test assessment of 588 adolescents, with different school performance levels, which were given an intelligence assessment test (Raven's Progressive Matrices). After processing the data obtained by the applied intelligence test, 70 respondents were chosen from each category of school performance, and they entered the second stage of testing. This procedure was aimed at matching the groups according to their intelligence quotient (IQ). The second stage of testing, during which the tests of attention were administered individually, with the exception of the Concentration Achievement Test (CAT), was entered by respondents who achieved an IQ score between 104 and 107 on the applied test, given that the largest number of respondents belonged to this category $(M=105)$ and given the fact that it can be expected that this intellectual level is not an obstacle for the attainment of excellent school performance. In the third stage, the chosen respondents solved the CAT in groups. It is important to note that school performance was expressed as the average performance in the classification period which preceded the testing. The average grade used in this research included only the grades in subjects in which verbal learning is significant (Serbian language, foreign language, history, geography, biology, chemistry, mathematics, physics, computer science, etc.). In the terms and procedures of statistical analysis, the categories of the school performance of respondents, classified as average grades, were processed as dependent variables:

- Insufficient performance (from 1 to 1.99)

- Sufficient performance (from 2 to 2.49)

- Good performance (from 2.50 to 3.49) 
- Very good performance (from 3.50 to 4.49 )

- Excellent performance (from 4.50 to 5.00 )

ANALYSIS PRO- A calculation of measures of central tendency and a calculation of CEDURES variability measures were used in terms of descriptive models. The Chi-square test, Student's T-test, simple linear correlation, Spearman's rank correlation coefficient, and the analysis of variance (ANOVA) were used in terms of analytical models.

\section{RESULTS}

Given that the primary aim of the research was an attempt to identify the components of attention that are relevant for school learning at an adolescent age, the Figures that follow show the arithmetic means of the achievements of respondents on the examined variables in relation to school performance.

The arithmetic means for the variable DS, which represents the total number of repeated digits, as a measure of the capacity of attention, shows an increasing trend in accordance with an increase in performance (Graf 11 ).

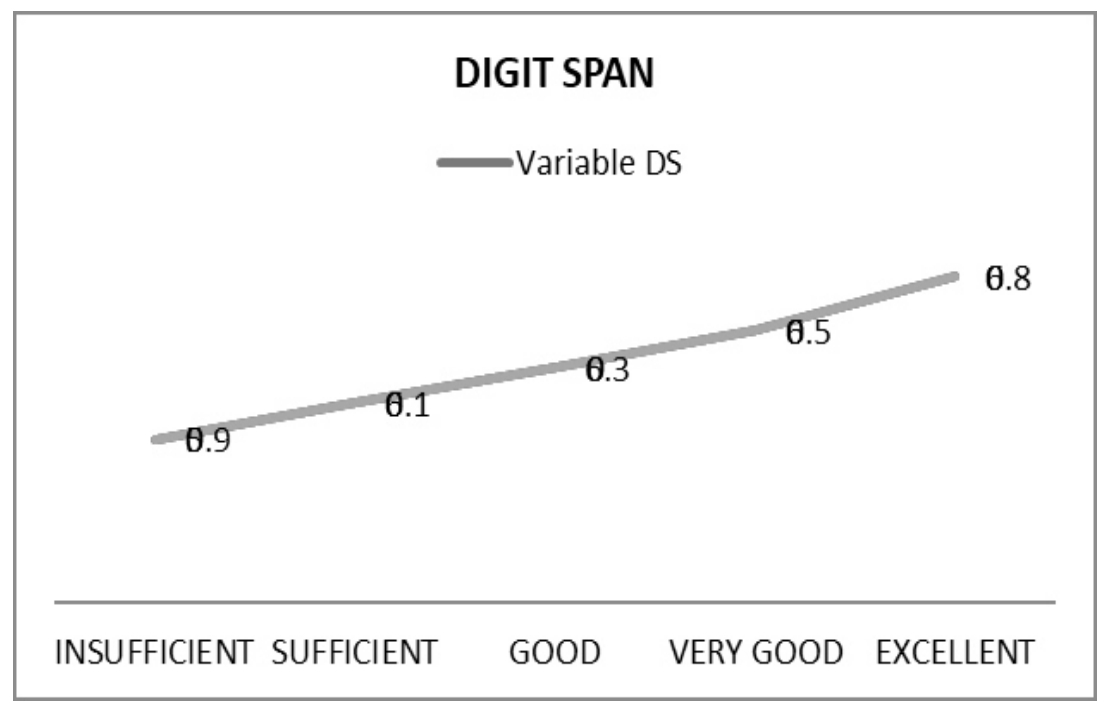

FIGURE 1: ARITHMETIC MEANS FOR THE VARIABLE DS (DigIT SPAN)

The arithmetic means for the variable NS (Number Symbols), which represents the number of successfully filled in symbols of numbers 
as a measure of attention selectivity and maintenance, increase continuously with an increase in performance.

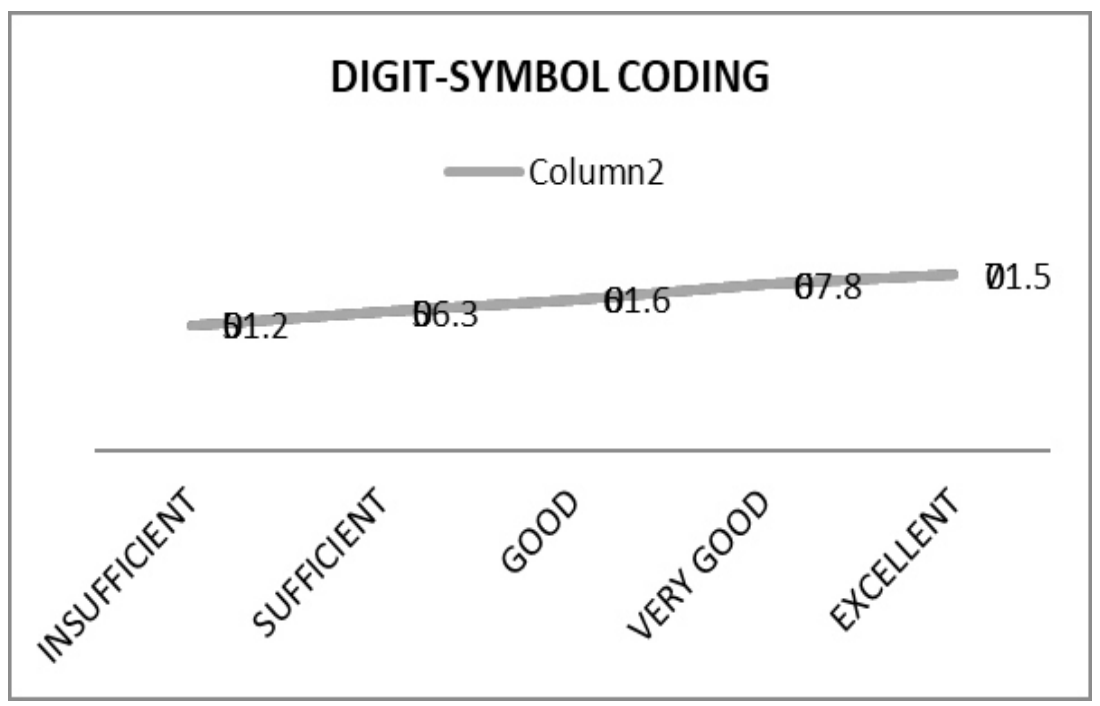

FiguRE 2. ARITHMETIC MEANS FOR THE VARIABLE NS (NumbER SyMBOLS)

The arithmetic means for the variable TMTTM1, which represents the total time needed for connecting the numbers from 1 to 25 , expressed in seconds, as a measure of visuospatial monitoring and concentration, show a decreasing tendency as school performance increases. The arithmetic means for the variable TMTTM2, which represents the total time needed for connecting the letters and numbers, expressed in seconds, as a measure of attention flexibility also decrease as performance increases (Figure 3).

The variable Strooptm 1 represents the total time, expressed in seconds, needed for reading the words with the interference of colour, as a measure of the selectivity of attention. It is evident that the time needed for the completion of this test decreases as performance increases. The variable Strooptm 2 represents the total time, expressed in seconds, needed for naming the colours with the interference of the conflicting word, as a measure of goal-oriented selectivity and resistance to distractions. It is also evident that students with higher school performance need less time to complete this test (Figure 4). 


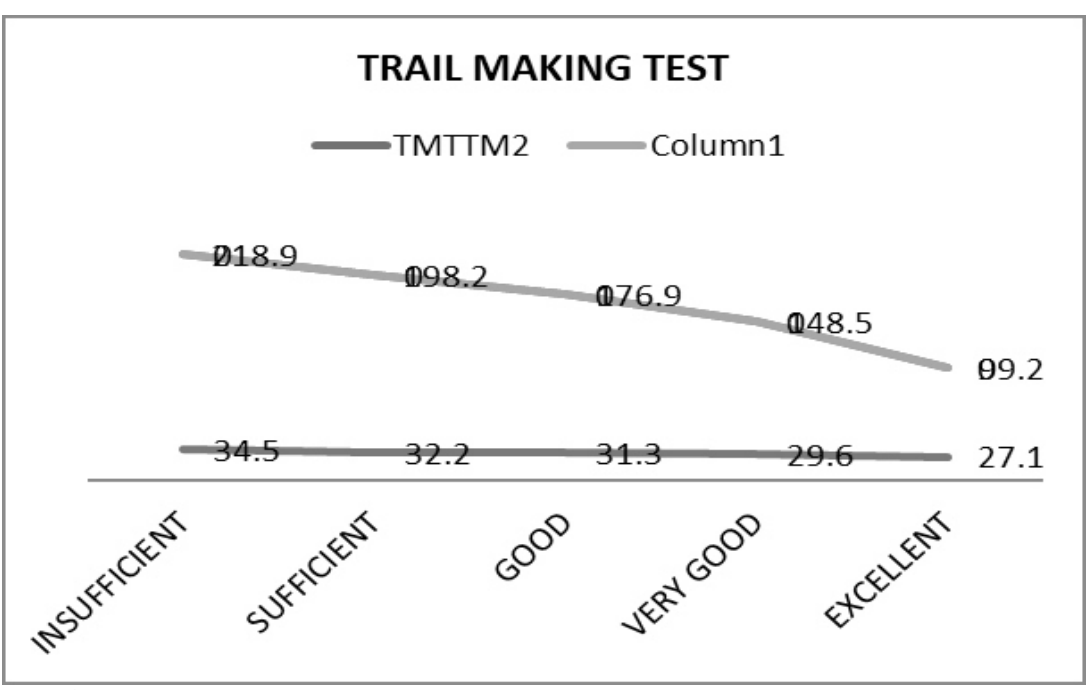

FIGURE 3. ARITHMETIC MEANS FOR THE VARIABLE TMTTM1 AND VARIABLE TMTTM2 FOR GROUPS WITH DIFFERENT SCHOOL PERFORMANCE LEVELS

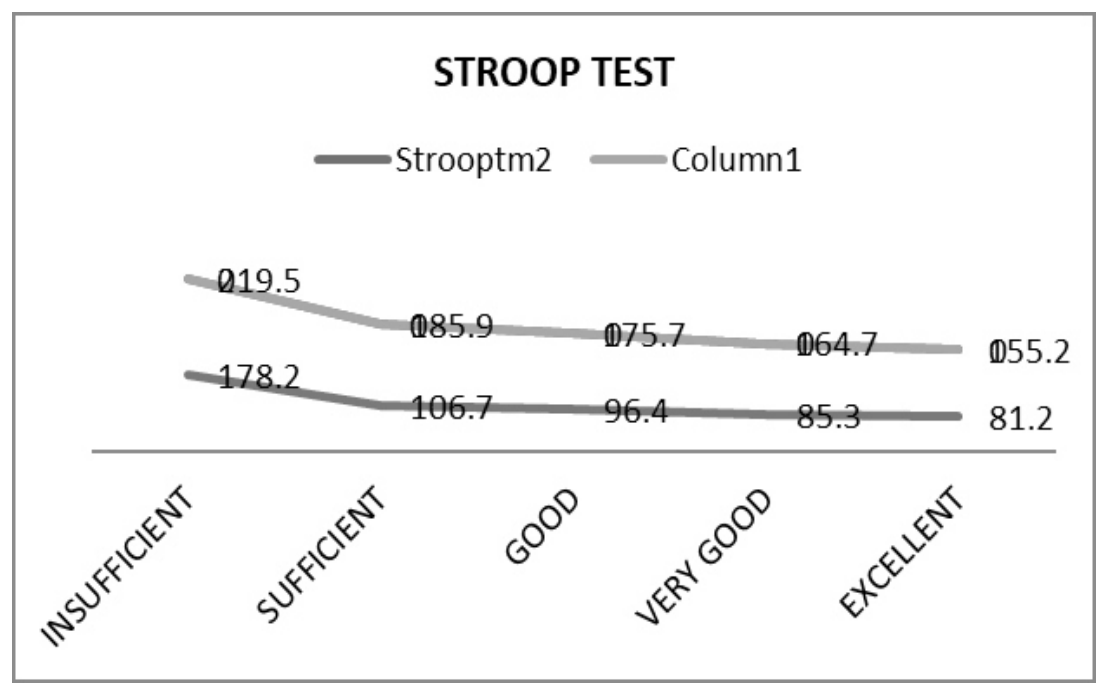

FigURE 4. ARITHMETIC MEANS FOR THE VARIABLES STROOPTM1 AND STROOPTM2 FOR GROUPS WITH DIFFERENT SCHOOL PERFORMANCE LEVELS

The variable CATT represents a total number of solved tasks, during a time period of 30 minutes, as a measure of the ability to sustain attention, of concentration and vigilance. The total number of solved tasks increases with an increase in respondents' perfor- 
mance. The variable CATC represents the number of correctly solved tasks as a measure of the tenacity of attention. The number of correctly solved tasks also increases with an increase in performance. The arithmetic mean for the group of excellent students is higher for a staggering 97 correctly solved tasks than the arithmetic mean for the group of insufficient students.

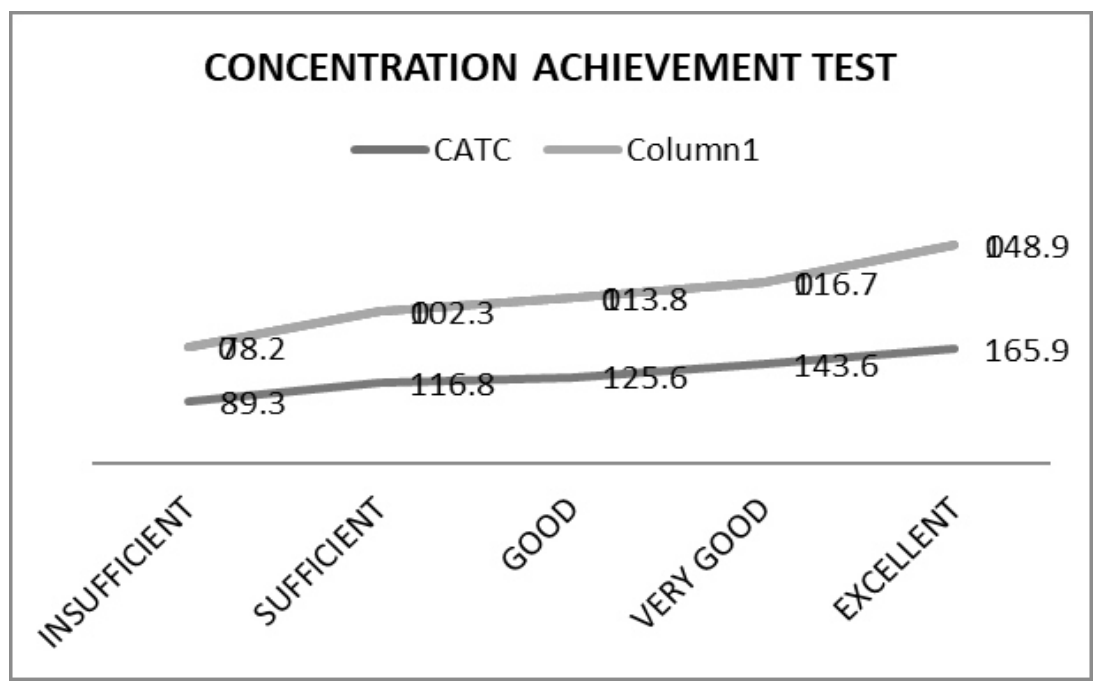

FIGURE 5. ARITHMETIC MEANS FOR THE VARIABLES CATT AND CATC FOR GROUPS WITH DIFFERENT SCHOOL PERFORMANCE LEVELS

The most relevant issue in this context is the issue of the significance of obtained differences in the achievements of respondents with different school performance levels. In order to determine this by using the method of the analysis of variance (ANOVA), the significance of differences in the achievements of groups of different ages on all tests and variables was tested.

On the Digit Span Test, the variable DS, the obtained differences were not found to be statistically significant (Table 1)

\begin{tabular}{llrrrrr}
\hline & & \multicolumn{1}{c}{ SUM } & DF & M & F & \multicolumn{1}{l}{ P } \\
\hline DS & between groups & 7.998 & 4 & 1.966 & 1.896 & 0.98 \\
& within groups & 119.029 & 114 & 1.069 & & \\
\hline
\end{tabular}

TABLE 1: THE SIGNIFICANCE OF DIFFERENCES BETWEEN GROUPS WITH DIFFERENT PERFORMANCE LEVELS ON THE Digit SPAN Test (VARIable DS) 
On the Digit-Symbol Coding Test, the variable NS, the differences between different age groups proved to be highly statistically significant (Table 2).

\begin{tabular}{llrrrrr}
\hline & & \multicolumn{1}{c}{ SUM } & DF & \multicolumn{1}{c}{ M } & F & \multicolumn{1}{l}{ P } \\
\hline NS & between groups & 924.172 & 4 & 234.545 & 2.621 & 0.000 \\
& within groups & 10189.64 & 114 & 88.334 & & \\
\hline \hline
\end{tabular}

TABLE 2: THE SIGNIFICANCE OF DIFFERENCES BETWEEN GROUPS WITH DIFFERENT PERFORMANCE LEVELS ON the Digit-Symbol Coding Test (VARIABle NS)

On the Trail Making Test (variable TMTTM1 as a measure of visuospatial monitoring and concentration) the difference between groups with different school performance levels did not prove to be statistically significant. The differences in recorded times on the second part of the test (variable TMTTM2 as a measure of concentration and the flexibility of attention) proved to be highly statistically significant (Table 3).

\begin{tabular}{llrrrr}
\hline & \multicolumn{1}{c}{ SUM } & \multicolumn{1}{c}{ DF } & \multicolumn{1}{c}{ M } & F & P \\
\hline TMTTM1 between groups & 301.621 & 4 & 75.576 & 0.451 & 0.587 \\
within groups & 14512.82 & 114 & 129.045 & & \\
TMTTM1 between groups & 546.67 & 4 & 9807.099 & 5.988 & 0.000 \\
within groups & 16845.6 & 114 & 1456.521 & & \\
\hline
\end{tabular}

TABLE 3: THE SIGNIFICANCE OF DIFFERENCES BETWEEN GROUPS WITH DIFFERENT PERFORMANCE LEVELS ON THE TRAIL MAKING TEST (VARIABLES TMTTM1 AND TMTTM2)

The first measured time on the Stroop Test (variable Strooptm1, naming of words with an interference of colour, as a measure of attention selectivity) is significantly associated with school performance. The second measured time on the Stroop Test (variable Strooptm2, naming of colours with an interference of a conflict word, as a measure of resistance to distractions) is highly significantly associated with the school performance of respondents.

The total number of solved tasks and the total number of correctly solved tasks (variables CATT and CATC, as indicators of attention maintenance and concentration) are highly significantly different between groups with different performance levels. 
Collection of Papers of the Faculty of Philosophy XLVII (3)/2017

\begin{tabular}{lllrlll}
\hline & & SUM & DF & M & F & \multicolumn{1}{l}{ P } \\
\hline Strooptm1 & between groups & 1213.435 & 4 & 314.452 & 2.147 & 0.057 \\
& within groups & 15423.21 & 114 & 134.123 & & \\
Strooptm2 & between groups & 31713.34 & 4 & 8941.117 & 6.654 & 0.000 \\
& within groups & 154449.5 & 114 & 1353.580 & & \\
\hline
\end{tabular}

TABLE 4: THE SIGNIFICANCE OF DIFFERENCES BETWEEN GROUPS WITH DIFFERENT PERFORMANCE LEVELS ON THE STROop Test (VARiables STROOPTM1 AND STROOPTM2)

\begin{tabular}{llrrrrr}
\hline & & SUM & DF & M & F & P \\
\hline CATT & between groups & 27126.187 & 4 & 7122.712 & 4514 & 0.000 \\
& within groups & 175818.6 & 114 & 1529.847 & & \\
\multirow{2}{*}{ CATC } & between groups & 294558.167 & 4 & 7381.216 & 4.212 & 0.000 \\
& within groups & 171486.7 & 114 & 1501.623 & & \\
\hline
\end{tabular}

TABLE 5: THE SIGNIFICANCE OF DIFFERENCES BETWEEN GROUPS WITH DIFFERENT PERFORMANCE LEVELS ON THE CONCENTRATION ACHIEVEMENT TEST (VARIABLEs CATT AND CATC)

The total sample in this research consisted of 170 respondents of both genders. Table 6 shows the descriptive indicators of achievements on all of the tests and variables for male and female respondents.

\begin{tabular}{llrrr}
\hline \hline VARIABLE & GENDER & $\mathrm{N}$ & $\mathrm{M}$ & \multicolumn{1}{c}{ SD } \\
\hline DS & male & 140 & 6.3 & 1.1 \\
& female & 140 & 6.2 & 1.1 \\
NS & male & 140 & 51.7 & 9.4 \\
& female & 140 & 58.2 & 8.5 \\
TMTTM1 & male & 140 & 32.8 & 11.9 \\
& female & 140 & 32.6 & 10.6 \\
TMTTM2 & male & 140 & 103.2 & 37.9 \\
& female & 140 & 102.8 & 43.2 \\
Strooptm1 & male & 140 & 87.2 & 12.6 \\
& female & 140 & 82.9 & 12.8 \\
DS & male & 140 & 176.4 & 39.9 \\
& female & 140 & 171.4 & 34.8 \\
NS & male & 140 & 124.3 & 48.2 \\
& female & 140 & 127.2 & 38.9 \\
\hline
\end{tabular}

TABLE 6: DESCRIPTIVE INDICATORS OF THE TOTAL SAMPLE IN RELATION TO GENDER 


\begin{tabular}{lllll} 
TMTTM1 & male & 140 & 119.4 & 49.2 \\
& female & 140 & 122.3 & 43.4 \\
\hline \hline
\end{tabular}

TABLE 6: DESCRIPTIVE INDICATORS OF THE TOTAL SAMPLE IN RELATION TO GENDER

By applying the T-test, an existence of a significance of differences between the values of the achievements of male and female respondents on the applied tests was examined. The results of the analyses have shown that girls and boys achieved results which did not statistically significantly differ. The exception is their achievement on the Digit-Symbol Coding Test. The number of correctly solved tasks on this test is highly significantly different when it comes to girls and boys $(T=-3.989, \mathrm{DF}=118, \mathrm{p}<0.01)$, in favour of girls. Girls have shown highly significantly better results than boys. Given that no significant differences were obtained, further analysis in relation to school performance was not relevant.

\section{DISCUSSION}

Starting from the knowledge that school learning requires the highest possible degree of volitional attention, that a number of undeniably intelligent and ambitious students have inadequate school performance, and that school performance has great significance in the lives of contemporary adolescents (Luria, 1976; Milovanović, 2001), this research was aimed at identifying the components of attention that are relevant for school learning. In this context, the key issue may not be the issue of the connection between attention and school performance, which is already implied, but the issue of whether potential attention deficits in students with inadequate school performance have a structure that we are able to detect by available and cost-effective diagnostic techniques and ultimately help adolescents.

According to the results of the analyses, the examined group of adolescents of the same age and equal intellectual levels, but with different school performance levels, have achieved very different results on almost all applied tests and measured variables. The examined groups of adolescents with different performance levels have indeed shown different score profiles on the applied techniques and significant differences in their achievements when it comes to individual variables. All results, i.e. the mean values of 
the results of examined subgroups, change depending on school performance, in the sense that the results are better as performance is higher.

On the Digit Span Test (Variable DS), despite the fact that the differences in the achievements of respondents are not statistically significant, a constant increasing tendency of arithmetic means can be observed. While a student with an insufficient performance can repeat an average of 5.9 digits, excellent students are able to repeat 6.8 digits. Greater efficiency of respondents with higher performance levels points to their greater capacity of attention, which can be explained by the role of resistance to distractions in solving this task. Excellent students obviously possess more stable attentional control functions, they are resistant to distractions and are therefore more efficient in focusing on the task, in this case on digit repetition.

The achievements on the Digit-Symbol Coding Test (Variable NS) show a very linear progression, starting from insufficient towards excellent performance. The difference in arithmetic means between groups with different performance levels is highly statistically significant. The average progression is 5 solved tasks by category of performance, so the difference between the respondents with insufficient performance and respondents with excellent performance equals 20 solved tasks. Given that the Digit-Symbol Coding Test is a valid test of attention maintenance, results suggest that students with higher performance levels have a greater ability to maintain their attention on the desired object more efficiently and for a longer period of time than students with lower performance levels.

The measured variables on the TMT test show the same tendency. The average time required for solving form $A$ and form $B$ of the test statistically significantly differ to a high degree, between groups with different performance levels. Better students need significantly less time to solve the tasks on this test. Excellent students solve the form B of the test as much as 119 seconds faster than insufficient students. Obviously, the results of this test indicate a significantly lower ability of students with insufficient performance, to organize and control the alternation of sequences, which could speak in favour of insufficient attention flexibility and, more broadly, insufficient attentional control. As a reminder, attentional control implies the ability to inhibit the first response, 
to delay the response and prolong attention maintenance in order to select the most appropriate response or meaningful activity.

The achievement curve for the Stroop Test shows the same dynamics as the previous ones. The decrease of time necessary for solving this test is continuously, intensively, and highly statistically significant with an increase in school performance. The time needed for reading the words with an interference of colours (variable Stooptm1) continuously decreases, with equal differences in performances of around 13 seconds. The time required for the naming of colours with the interference of words (variable Strooptm2) expresses a tendency of a pronounced decrease in the function of school performance. The mean difference between groups with different school performance levels is around 19 seconds. Excellent students are faster than students with insufficient school performance levels for as much as 97 seconds. Given that the Stroop Test is almost unquestionable in terms of its validity and that, as such, it represents a reliable indicator of goal-oriented selectivity and resistance to distractions, the obtained results could be interpreted as very clear indicators of the significance of these components of the function of attention in achieving a better school performance.

On the test of concentration, the total number of solved tasks shows an almost linear progression from the weakest to the best performance. The total number of solved tasks (variable CATtm1), between consecutive groups with different performance levels, differs by about 15 tasks. The number of correctly solved tasks (variable CATtm2) differs between consecutive groups by about 14 tasks. While excellent students correctly solve an average of about 116 tasks, students with insufficient performance levels solve an average of 78. This test, as is the case with the Stroop Test, is of unquestionable validity and represents a reliable measure of goal-orientation, mental effort maintenance, and concentration.

The achievement profile of students with lower performance levels is quite obviously different from the achievement profile of students with higher performance levels. On the basis of the obtained values of the significance of differences between groups, the following variables can be distinguished, along with the implied components of attention that they reflect: the number of correct number symbols on the Digit-Symbol Coding Test, as a measure of selectivity and concentration; the time period required for solving the form A and form B of the TMT, as a measure of flex- 
ibility and concentration; the time required for solving the Stroop Test, as a measure of selectivity and resistance to distractions; and the total (and correct) number of solved tasks on the CAT, as a measure of concentration and mental set maintenance. The mentioned variables and the presumed functions that they measure: selectivity, flexibility, resistance to distractions, and concentration - are best at discriminating between groups in relation to their school performance and are related to school performance in the most significant sense.

As a reminder, research into volitional attention is usually organized in relation to learning difficulties of younger school children (Brock \& Bohlin, 2004; Swanson, 2011) or associated with ADHD syndrome (Sonuga-Barke et al., 2011). The problem of distractibility was particularly often discussed in literature as a problem of maintaining the required level of alertness needed for solving school tasks and learning lessons, as well as for an active participation in lectures, for a longer period of time (DuPaul et al., 2002). Despite the fact that, in everyday school practice, there are adolescents who exhibit an extremely rapid onset of fatigue when learning, a very bad learning performance and frequent interruptions in the flow of attention, this problem was dealt with by only a small number of researchers. For these reasons, it can be said that knowledge about the problems of attention does not follow developmental trends and all of the specificities of the functioning of attention, from its elementary forms to full maturity (Anderson et al., 2001). The development of attention after the twelfth year of life is what remains outside the scope of interest of researchers. Difficulties manifested by adolescents in school learning are usually interpreted and treated as emotional difficulties related to this age or in terms of a lack of motivation (Eysenck et al., 2007). Due to the fact that volitional attention is socially conditioned, it can be concluded, from everything that has been said, that the effects on the development of attention are far from a planned and systematic activity. If the frequently inadequate treatment of learning disabilities of intelligent and motivated adolescents is added to this, the theoretical and practical implications of this lack become apparent.

The research of the development of attention in adolescence on a sample of 800 respondents, aged 12-19 years, with the use of instruments that were also used in this study, has shown that the "upside-down" attentional control, along with the functions of 
attention, such as goal-oriented selectivity, resistance to distractions, attention maintenance, and concentration, are developed through adolescence and reach their maximum development at different ages (Milovanović, 2012). A connection between these components of attention and school performance, which was confirmed in this research, can be discussed in the light of these findings. Namely, the components of attention related to school performance reach their developmental maximum at different ages during adolescence. Based on the obtained findings, it is possible to assume that in adolescents with lower performance levels they are still underdeveloped (Navarro et. al. 2011). As a reminder, the examined components of attention are associated with the prefrontal regions of the brain. Neurophysiological studies confirm that morphological changes and a maximum of metabolic activity in the prefrontal regions lag behind other regions of the brain (Colby, 1991), that synaptic consolidation lasts at least through the entire adolescence (Intrilligator \& Cavanagh, 2001) and that the myelinogenesis in these regions takes place until the third decade of life (Fields, 2014). For these reasons, we believe that the exclusion of attention during the search for the causes of school failure of adolescents can pose a serious oversight with lasting consequences.

In this research, no significant differences in the performance of adolescents of different genders on the applied attention tests were found.

CONCLUSION By examining the correlation between attention and school performance on a total sample of 350 adolescents, by using instruments that possess a determined validity, results were obtained which can be interpreted as an indication that components of attention, first and foremost goal-oriented selectivity, resistance to distractions, attention maintenance, and concentration, represent significant factors in the school performance of adolescents. As part of a broad plan of adolescents to finish a particular school, maintain their level of performance, and attain their life goals, school learning implies clearly formulated intentions, the ability to plan, specify a strategy, and execute concrete actions as well as the ability of self-correction. All of this requires goal-oriented selectivity, an ability to suppress interfering stimuli, to maintain attention, concentrate on specific content, and therefore, it requires stable volitional attention. For these reasons, we believe that without 
taking into account the ability of directing behaviour towards achieving personal goals and without knowing the characteristics of volitional attention, the performance or failure of adolescents in school learning cannot be understood. Since the starting point of the paper is based on the knowledge that an inadequate school performance of adolescents is, in practice, usually interpreted without taking into account the characteristics of their attention, we consider the obtained results significant, given that they can be a milestone in the search for specific answers to the question of how to help adolescents whose school performance levels are not appropriate to their abilities and effort. The results also imply the necessity of a planned and systematic action in the direction of encouraging the development of these components of attention, which are a necessary precondition for any goal-oriented activity and school performance as well.

REFERENCES Astle, D. E., \& Scerif, G. (2009). Using Developmental Cognitive Neuroscience to Study Behavioral and Attentional Control. Developmental Psychobiology, 51 (2), 107-118.

Awh E., Armstrong, K. M., \& Moore, T. (2006). Visual and oculomotor selection: links, causes and implications for spatial attention. Trends in Cognitive Sciences, 10, 124-130.

Anderson, V. A., Anderson, P., Northam, E., Jacobs, R., \& Catroppa, C. (2001). Development of executive functions through late childhood and adolescence in an Australian sample. Developmental Neuropsychology, 20 (1), 385-406.

Baddeley, A. (2003). Working memory: looking back and looking forward. Nat. Rev. Neurosci, 4, 829-839.

Boekaerts , M., \& Corno, L. (2005). Self-Regulation in the Classroom: A Perspective on Assessment and Intervention. Applied psychology: an international review, 54 (2), 199-231.

Brocki, K.C., Bohlin, G. (2004). Executive functions in children aged 6 to 13: A dimensional and developmental study. Developmental Neuropsychology, 26 (2), 571-593.

Banich, M. (2009). Executive function: The search for an integrated account. Current Directions in Psychological Science, 18, 89-94.

Chan, R.C.K., Shum, D., Toulopoulou, T., Chen, E.Y.H. (2008). Assessment of executive functions: Review of instruments and identification of critical issues. Archives of Clinical Neuropsychology, 23 (2), 201-216. 
Colby, C. L. (1991).The neuroanatomy and neurophysiology of attention. Journal of Child Neurology, 6, 90-118.

DuPaul, G. J., Stoner, G., \& O’Reilly, M. J. (2002). Best practices in classroom interventions for attention problems. In: A. Thomas \& J. Grimes (Eds.), Best Practices in School Psychology, 2 (pp. 1115-1127). Washington, DC: National Association of School Psychologists. Attention problems and academic achievement 28.

Diamond, A. (2013). Executive functions. Annual Review of Psychology, 64, 135168.

Deary, I. J., \& Johnson W. (2010). Intelligence and education: Causal perceptions drive analytic processes and therefore conclusions. International Journal of Epidemiology, 39, 1362-1369.

Eisenberg N., Smith, C. L., Sadovsky, A., \& Spinrad, T. L. (2004). Effortful control: Relations with emotion regulation, adjustment, and socialization in childhood. In: R. F. Baumeister, K. D. Vohs (Eds.), Handbook of self-regulation: Research, theory, and applications (pp. 259-282). New York: Guilford.

Eysenck, M., Kerakshan, N., Santos, R., \& Galvo, M. (2007). Anxiety and cognitive performance: Attentional control theory. Emotion, 7 (2), 336-353.

Fields, D. R. (2014). Myelin Formation and Remodeling. Cell 156 (1-2), 15-17.

Guy, S. C., Isquith, P.K. Giola, G. A. (2004). Behavior rating inventory of executive function (Self-report version ed.). Odessa, Fl: Psychological Assessment Resources.

Gadžić, A. \& Milojević, A. (2009). Školski uspeh i status adolescenata u razredu. Teme, 33 (4), 1379-1389.

Gottschling, J., Spengler, M., Spinath, B., \& Spinath, F. M. (2012). The prediction of school achievement from a behavior genetic perspective: Results from the German twin study on cognitive ability, self-reported motivation, and school achievement (CoSMoS). Personality and Individual Differences, 53, 381-386.

Havelka, N. (2000). Učenik i nastavnik u obrazovnom procesu. Beograd: Zavod za udžbenike.

Hinshaw, S. P. (1992). Externalizing Behavior Problems and Academic Underachievement in Childhood and Adolescence: Causal Relationships and Underlying Mechanisms. Psychological Bulletin, 111 (1), 127-155.

Intrilligator, J., \& Cavanagh, P. (2001). The spatial resolution of visual attention. Cognitive Psychology, 43 (3), 171-216.

Knudsen, E. (2007). Fundamental components of attention. Annual Review of Neuroscience, 30, (57-78). 
Lezak, M. D., Howieson, D. B., \& Loring, D. W. (2004). Neuropsychological Assessment (4th ed.). New York: Oxford University Press.

Luria, A. R. (1973). The working brain. Peguin: London.

Madeeha, K., \& Abdulbari, B. (2009). Factors contributing to school failure among school children in very fast developing Arabian Society. Oman Medical Journal, 24 (3), 212-217.

Malenka, RC., Nestler, E. J., \& Hyman, S. E. (2009). Chapter 13: Higher Cognitive Function and Behavioral Control. In: A. Sydor, RY. Brown (Eds.), Molecular Neuropharmacology: A Foundation for Clinical Neuroscience (2nd ed.). New York: McGraw-Hill Medical, 313-321.

Moss, E., \& St-Laurent, D. (2001). Attachment at school age and academic performance. Developmental Psychology, 37 (6), 863-874.

Milovanović, R. (2001). Pažnja i učenje. Beograd: Centar za primenjenu psihologiju.

Milovanović, R. (2012). Razvoj egzekutivnih komponenti funkcija pažnje u adolescenciji. Engrami, 34 (1), 5-20.

Mirkov, S. (2007). Samoregulacija u učenju - primena strategija i uloga orijentacija na ciljeve. Zbornik Instituta za pedagoška istraživanja, 39 (2), 309-328.

Montalvo, F. T \& Gonzales Torres, M. C. (2004). Self-Regulated Learning: Current and Future Directions. Electronic Journal of Research in Educational Psychology, 2 (1), 1-34.

Maunsell, J.H, Cook, E.P. (2002). The role of attention in visual processing. Philosophical Transactions of the Royal Society Biological Sciences, 357, 1063-1072.

Nikolašević, Ž., Bugarski- Ignjatović, V., Milovanović, I., i Raković, S. (2014). Inteligencija i školsko postignuće u svetlu naslednih sredinskih činilaca. Primenjena psihologija, 7 (3), 381-400.

Navarro, J., Aguilar, M., Alcalde, C., Ruiz, G., Marchena, E., \& Menacho, I. (2011). Inhibitory processes, working memory, phonological awareness, naming speed, and early arithmetic achievement. The Spanish Journal of Psychology, 14 (2), 580-588.

Pintrich, P. R. (1999). The Role of Motivation in Promoting and Sustaining Self-Regulated Learning. International Journal of Educational Research, 31 (2), 459-470.

Raven, J., Raven, J. C., \& Court, J. H. (1998). Raven manual: Section 1, general overview. Oxford, UK: Oxford Psychologists Press Ltd.

Rayneri, L. J., Gerber, B. L., \& Wiley L. P. (2006). The relationship between classroom environment and the learning style preferences of gifted middle school students and the impact on levels of performance. Gifted Child Quarterly, 50 (2), 104-118. 
Rueda, M. R., Posner, M. L., \& Rothbart , M. K. (2005). The Development of Executive Attention: Contributions to the Emergence of Self-Regulation. Developmental Neuropsychology, 28 (2), 573-594.

Spinath, B., Spinath, F. M., Harlaar, N., \& Plomin, R. (2006). Predicting school achievement from general cognitive ability, self-perceived ability, and intrinsic value. Intelligence, 34, 363-374.

Stroop, J. R. (1935). Studies of interference in serial verbal reactions. Journal of Experimental Psychology, 18, 643-662.

Sonuga-Barke, E. J. S., Koerting, J., Smith, E., McCann, D. C., \& Thompson, M. (2011). Early detection and intervention for attention-deficit/hyperactivity disorder. Expert Review of Neurotherapeutics, 11 (4), 557-563.

Swanson, L. (2011). Working memory, attention, and mathematical problem solving: A longitudinal study of elementary school children. Journal of Educational Psychology, 103 (4), 821-837.

Vigotski, S. L. (1996). Problemi razvoja psihe. Beograd: Zavod za udžbenike i nastavna sredstva.

Vigotski, S. L. (1934). Thought and language. Cambridge, M. A: MIT Press.

Washburn, DA (2016). The Stroop effect at 80: The competition between stimulus control and cognitive control. Journal of the Experimental Analysis of Behavior, 105 (1), 3-13.

Zimmerman, B. J. (1990). Self-Regulated Learning and Academic Achievement: An Overview. Educational Psychologist, 25 (1), 3-17.

РАДМИЛА Б. МИЛОВАНОВИЋ

УНИВЕРЗИТЕТ У КРАГУЈЕВЦУ

ФАКУЛТЕТ ПЕДАГОШКИХ НАУКА - ЈАГОДИНА

РЕЗИМЕ

ПАЖЬА КАО ФАКТОР ШКОЛСКОГ УСПЕХА АДОЛЕСЦЕНАТА

Пажња представља језгро когнитивне активности, основни је елемент сврсисходне обраде информација и кључни фактор у саморегулацији која је неопходна за школски успех. Поред свих недостатака актуелног система оцењивања у школама, школски успех изражен школским оценама и даље представља важан индикатор успеха ученика у реалном свету, основни је показатељ образовних постигнућа и сведочанство које ученика формално идентификује као више или мање успешну особу. Истраживања пажње и њених компоненти (циљем усмерена селективност, отпорност на дистракције, одржавање и концентрације) најчешће 
су организована у вези са проблемима учења деце млађег школског узраста или у вези са проблемима деце и адолесцената са развојним хиперкинетским синдромом. Преглед литературе указује на скоро потпуно одсуство истраживања проблема пажње у контексту школског успеха адолесцената опште популације. То може бити један од разлога што се неадекватан школски успех неоспорно интелигентних адолесцената најчешће у школској пракси објашњава емоционалним факторима упркос томе што сами адолесценти са неадекватним школским успехом често наводе као опис својих тешкоћа у учењу „лошу концентрацију“ док их наставници описују као „ непажљиве“. Полазећи од значаја школског успеха за опште развојне токове, значаја пажње у контексту школског учења и недостатка истраживања повезаности пажње и школског успеха адолесцената, циљ овог истраживања је настојање да се идентификују компоненте пажње које су релевантне за школско учење на млађем адолесцентном узрасту. Поред тога, циљ истраживања је и утврђивање евентуалних разлика с обзиром на пол ученика. Укупни узорак је чинило 350 ученика (5 група ученика првог разреда средњих школа различитог успеха/ по 70 ученика у свакој категорији школског успеха: недовољан, довољан, добар, врло добар и одличан) из различитих градова Србије, узраста између од 14 и 16 година (м=15.2; Сд=0.319) уједначених по коефицијенту интелигенције (м=105; мин 104, мах 107). Узорак је обухватио по 175 ученика оба пола. Коришћени су следећи инструменти за мерење компоненти функција пажње: Дигит спан Тест, Шифра, Траил Макинг Тест, Стооп Тест, Тест концентрације и достигнућа (за мерење компоненти пажње), Равенове прогресивне матрице (за мерење интелигенције). У терминима и процедурама статистичке анализе обрађивано је постигнуће на овим тестовима као скуп независних варијабли и то: об (опсег бројева) - највећи укупан број поновљених цифара као мера капацитета пажње, С (симболи бројева) - број успешно уцртаних симбола као мера флексибилности и вигилности пажње, ТМТвр1-укупно време у секундама потребно за повезивање бројева као мера визуоспацијалног праћења и концентрације, Строопвр 1 (читање речи уз интерференцију боје) - укупно време у секундама као мера селективности пажње, Строопвр 2 (именовање боја уз интерференцију конфликтне речи) - укупно време у секундама као мера отпорности на дистракције, ТКдУ - укупан број решених задатака за 30 минута као мера одржавања пажње, концентрације и ви- 
гилности, ТКдТ - број тачно решених задатака као мера одржавања менталног сета и тенацитата пажње. Резултати су показали да је школски успех високо значајно повезан са одређеним склопом компоненти функција пажње (циљем усмерена селективност, отпорност на дистракције, одржавање пажње и концентрације) те да се постигнуће ученика са слабим школским успехом значајно разликује од постигнућа ученика са бољим школским успехом (п<0.01). Према резултатима анализа испитивана група адолесцената истог узраста, уједначеног интелектуалног нивоа али различитог школског успеха показала је значајно различито постигнуће на скоро свим примењеним тестовима и мереним варијаблама. Испитиване групе адолесцената различитог успеха заиста су показале различите профиле скорова на примењеним техникама и значајне разлике у постигнућима на појединим варијаблама. Сви резултати, односно средње вредности постигнућа испитиваних подгрупа значајно се мењају у зависности од школског успеха у смислу бољих резултата што је успех већи. Будући да се у раду полази од сазнања да се неадекватан школски успех адолесцената у пракси углавном тумачи ठез узимања у обзир карактеристика њихове пажње, добијене резултате сматрамо значајним с обзиром да могу бити путоказ у трагању за конкретним одговорима на питање како помоћи адолесцентима чији школски успех није адекватан њиховим способностима и уложеном труду. Резултати имплицирају и неопходност планског и систематског деловања у правцу подстицања развоја ових компоненти пажње које су неопходан услов сваке циљем усмерене активности и школског успеха такође. Осим тога резултати указују и на потребу конципирања едукативног програма с циљем подстицања развоја процењиваних компоненти пажње како би адолесценти постигли школски успех адекватан својим интелектуалним способностима.

КљУчнЕ РЕчи: контролне функције пажње, циљем усмерено понашање, саморегулација у учењу, школски успех адолесцената.

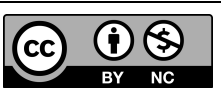

Овај чланак је објављен и дистрибуира се под лиценцом Creative Commons Ауторство-Некомерцијално Међународна 4.0 (СС BY-NC 4.0 | https://creativecommons.org/licenses/by-nc/4.0/).

This paper is published and distributed under the terms and conditions of the Creative Commons Attribution-NonCommercial International 4.0 licence (CC BY-NC 4.0 | https://creativecommons.org/licenses/by-nc/4.0/). 